\title{
PENGARUH PENERAPAN E-FILLING DAN PEMAHAMAN PERPAJAKAN TERHADAP KEPATUHAN WAJIB PAJAK ORANG PRIBADI PADA KANTOR PELAYANAN PAJAK BATAM SELATAN
}

\author{
yentina siregar \\ Fakultas Ekonomi, Universitas Riau Kepulauan \\ yentinasiregar@gmail.com
}

\begin{abstract}
The implementation of e-filling is a step that the DGT expects to be able to improve individual taxpayer compliance. Many factors that can affect taxpayers are still not compliant in paying or reporting annual tax returns, which is perhaps one of them is understanding taxation. This research is quantitative with the sampling technique used is purposive sampling. The criteria set for taking samples in this study are individual taxpayers who have used e-filling and registered with the South Batam KPP and collected data using questionnaires distributed online and directly to respondents the number of questionnaires distributed was 110 respondents and those who returned and can be processed as many as 105 respondents. The results obtained from this study are (1) the application of e-filling has a significant effect on individual taxpayer compliance with a sig value of 0.038 (2) understanding of taxation has a significant effect on individual taxpayer compliance with a sig value of 0.002 (3) simultaneously the application of e-filling and understanding of taxation have a significant effect on individual taxpayer compliance with a value of sig 0,000.
\end{abstract}

Keywords: Compliance of Individual Taxpayers, Implementation of E-filling, Understanding of Taxation.

\begin{abstract}
ABSTRAK
Penerapan e-filling adalah langkah yang diharapkan DJP dapat meningkatkan kepatuhan wajib pajak orang pribadi.Banyak faktor yang dapat mempengaruhi wajib pajak masih tidak patuh dalam membayar ataupun melaporkan SPT Tahunan, yaitu mungkin salah satunya adalah pemahaman perpajakan.Penelitian ini bersifat kuantitaif dengan teknik pengambilan sampel yang digunakan adalahpurposive sampling. Kriteria yang ditetapkan untuk mengambil sampel dalam penelitian ini adalah wajib pajak orang pribadi yang sudah mengguanakn e-filling dan terdaftar di KPP Batam Selatandan pengumpulan data menggunakan kuesioner yang disebar secara online dan langsung kepada responden jumlah kuesioner yang disebar sebanyak 110 respondendan yang kembali dan dapat diolah sebanyak 105 responden.. Hasil yang diperoleh dari penelitian ini adalah (1) penerapan efilling berpengaruh signifikan terhadap kepatuhan wajib pajak orang pribadi dengan nilai sig 0,038 (2) pemahaman perpajakan berpengaruh signifikan terhadap kepatuhan wajib pajak orang pribadi dengan nilai sig 0,002 (3) secara simultan penerapan e-filling dan pemahaman perpajakan berpengaruh signifikan terhadap kepatuhan wajib pajak orang pribadi dengan nilai sig 0,000 .
\end{abstract}

Kata Kunci : Kepatuhan Wajib Pajak Orang Pribadi, Penerapan E-filling, Pemahaman Perpajakan.

PENDAHULUAN

Perkembangan teknologi yang semakin canggih membuat DJP juga 
memanfaatkannya dalam pelayanan yang diberikan kepada wajib pajak orang pribadi, yaitu dengan menerbitkan efiiling. E-fiiling adalah cara menyampaikan SPT tahunan secara online tanpa wajib pajak perlu lagi ke KPP atau ke DJP untuk melaporkan SPT. Sistem efilling yang resmi diterbitkan pada tanggal 24 Januari 2005, dapat memberi kemudahan terhadap wajib pajak orang pribadi karena dengan e-filling wajib pajak orang pribadi dapat melalukan pengisian pelaporan kapan saja dan dimana saja sehingga diharapkan tidak adalagi alasan tidak ada waktu untuk melaporkan SPT.

Berdasarkan dari Pasal 1 angka 1 UU No. 6 Tahun 1983 yang kemudian disempurnakan dengan $U U$ No. 28 Tahun 2007 tentang Ketentuan umum dan tata cara perpajakan. Pajak adalah "kontribusi wajib kepada negara yang terutang oleh orang pribadi atau badan yang bersifat memaksa berdasarkan Undang Undang, dengan tidak mendapat timbal balik secara langsung dan digunakan untuk keperluan negara bagi sebesar-besarnya kemakmuran rakyat."Kontribusi wajib pajak dapat menentukan seoarang wajib pajak patuh atau tidak terhadap kewajibannya.Ada beberapa faktor yang dapat mempengaruhi kepatuhan wajib pajak membayar pajak.

Pemahaman mungkin salah satu faktor seorang wajib pajak dapat dikatakan patuh atau tidak, karena wajib pajak yang tidak paham apa fungsi pajak dan pengetuahuan lainnya tentang perpajakan sehingga wajib pajak tidak mengetahui itu kewajibannya.

Untuk mewujudkan wajib pajak yang patuh dispenda menggunakan sistem self assesment, sistem ini merupakan reformasi dari sistem official assesment. Sistem self assesment adalah sistem dimana Wajib Pajak diberi kepercayaan untuk menghitung dan melaporkan sendiri pajak yang terutang oleh Wajib Pajak, sedangkan petugas pajak sendiri bertugas untuk mengawasinya. Dimana berarti dengan sistem ini dapat dilihat tingkat kepatuhan wajib pajak dalam melaporkan kewajibannya karena sistem ini tergantung pada kesadaran wajib pajak, akan tetapi masih banyak wajib pajak yang belum patuh malporkan dan membayar pajak.

Berdasarkan Tjahono (2018) menjelaskan sampai puncak pelaporan SPT Tahunan PPH orang pribadi tangga 31 maret 2018, kepatuhan penyampaian laporan belum mencapai target yang ditentukan yaitu 64,5\% untuk triwulan 1 . Tahun 2016 ada sekitar 32 juta wajib pajak yang terdaftar, yang menyerahkan SPT ada 20 juta tapi realisasinya hanya 12 juta atau sekitar 65\%. Tahun 2017 sudah meningkat menjadi $70 \%$ sedangkan dinegara lain bisa mencapai $75 \%$ - 80\%. Dapat dilihat bahwa diindonesia tingkat kepatuhan wajib pajak masih rendah.

Sehingga untuk meningkatkan tingkat kepatuhan wajib pajak Direktorat Jendral Pajak selalu mengoptimalkan pelayanan.Salah satunya direktorat jendral pajak meluncurkan produk E-filling atau Elektronik Filing System. Adanya sistem ini diharapakan dapat meningkatkan kepatuhan wajib pajak dalam melaporkan SPT tahunannya karena dengan sistem ini wajib pajak dapat melaporkan SPTnya dengan mudah kapan saja dan dimana saja tampa harus mendatangi kantor pelayanan 
pajak. Akan tetapi faktanya masih banyak wajib pajak yang belum paham menggunakan sistem ini, padahal banyak manfaat yang didapat dengan menggunakan sistem e-filling.Adapun faktor kesadaran wajib pajak yang masih rendah dapat menjadi salah satu penyebab wajib pajak orang pribadi tidak patuh.

Kurangnya kesadaran wajib pajak dalam membayar pajak salah satu faktornya adalah bagaimana pemahaman dan pengetahuan wajib pajak itu sendiri tentang perpajakan, karena wajib pajak yang sudah memilik NPWP belum tentu paham tetntang perpajakan. Seorang wajib pajak yang memiliki pemahaman dan pengetahuan perpajakan pasti akan sadar dan patuh dalam memenuhi kewajibannya sebagai wajib pajak.

Di Batam sendiri kesadaran wajib pajak dalam membayar dan melaporkan surat pemberitahuan bukti pembayaran pajak masih rendah. Menurut lelana (2015) pada 2014 dari 253.258 wajib pajak orang pribadi karyawan, sebanyak 93.541 yang melaporkan SPT dan dari 159.729 wajib pajak OP pekerjaan bebas, hanya 62.211 yang melaporkan SPT, katanya di Batam. Menurut data dari KPP Batam Selatan pada tahun 2016 jumlah SPT tahunan orang pribadi adalah 55.635 wajib pajak dan pada tahun2017 mengalami penurunan yaitu jumlah SPT tahunan hanya berjumlah 47.446 yang artinya tingkat kepatuhan wajib pajak orang pribadi masih rendah.

Penelitian yang sama pernah dilakukan oleh ,Agustiningsih (2016) , hasil penelitiannya adalah (1) Penerapan $e$-filing berpengaruh positif dan signifikan terhadap kepatuhan wajib pajak dengan nilai koefisien determinasi 0,454 . (2) Tingkat pemahaman perpajakan berpengaruh positif dan signifikan terhadap kepatuhan wajib pajak dengan koefisien determinasi 0,444. (3) Kesadaran wajib pajak berpengaruh positif dan signifikan terhadap kepatuhan wajib pajak dengan nilaikoefisien determinasi 0,621. Peneliti berikutnya adalah Jayanti (2017), hasil penelitiannya menyebutkan (1) variabel penerapan sistem e-filing berpengaruh signifikan terhadap kepatuhan wajib pajak. (2) pemahaman perpajakan tidak berpengaruh signifikan terhadap kepatuhan wajib pajak. (3) kemudian selanjutnya variabel kesadaran wajib pajak tidak berpengaruh signifikan terhadap kepatuhan wajib pajak. Berdasarkan hasil peneliti Nursalim (2017) menunjukkan (1) penerapan sistem e-filing berpengaruh positif dan signifikan terhadap kepatuhan wajib pajak. (2) pemahaman internet dapat memoderisasi murni positif dan signifikan terhdap kepatuhan wajib pajak. Menurut Havid (2014), hasil penelitiannya menyebutkan penerapan e-fiiling berpengaruh signifikan terhadap tingkat kepatuhan wajib pajak.

Berdasarkan permasalahan diatas peneliti tertarik mengangkat judul "Pengaruh Penerapan E-filling Dan Pemahaman Perpajakan Terhadap Kepatuhan Wajib Pajak Orang Pribadi Pada Kantor Pelayanan Pajak Batam Selatan"

\section{Metode Penelitian}

\section{Jenis Data}

Jenis data yang digunakan adalah metode penelitian dengan analisis regresi 
berganda.Menurut Hasan (2008), analisis linier berganda adalah di mana variabel terikatnya (Y) dihubungkan atau dijelaskan lebih dari satu variabel, mungkin dua, tiga, dan seterusnya variabel bebas $(\mathrm{X} 1, \mathrm{X} 2, \mathrm{X} 3, \ldots, \mathrm{Xn})$ namun masih menunjukkan diagram hubungan yang linear. Penambahan variabel bebas ini diharapkan dapat lebih menjelaskan karakteristik hubungan yang ada walaupun masih saja ada variabel yang terabaik.

Sumber data yang digunakan adalah data primer. MenurutSekaran ( 2011), Data primer adalah data yang mengacu pada informasi yang diperoleh dari tangan pertama oleh peneliti yang berkaitan dengan variabel minat untuk tujuan spesifik studi. Sumber data primer adalah responden individu, kelompok fokus, internet juga dapat menjadi sumber data primer jika koesioner disebarkan melalui internet

\section{Populasi dan Sampel populasi}

Menurut Sugiyono (2011), populasi adalah wilayah generalisasi yang terdiri atas: obyek/subyek yang mempunyai kualitas dan karakteristik tertentu yang ditetapkan oleh peneliti untuk dipelajari dan kemudian ditarik kesimpulannya. Populasi pada penelitian ini adalah wajib pajak yang terdaftar di KKP Batam Selatan yang sudah menggunakan sistem e-filling.Wajib pajak orang pribadi yang terdaftar pada kantor pelayanan pajak selatan berjumlah 298.648.

\section{Sampel}

Menurut Sugiyono( 2011), sampel adalah bagian atau jumlah dan karakteritik yang dimiliki oleh populasi tersebut.
Penentuan jumlah sampel dalam penelitian ini menggunakan rumus slovin (1960). Rumus slovin menurut Sugiyono (2011) adalah sebagai berikut :

$$
n=\frac{N}{1+N e^{2}}
$$

Keterangan :

$\mathrm{n}$ : sampel

$\mathrm{N}$ : populasi

$\mathrm{e}:$ margin of eror yang diinginkan

Jumlah SPT tahunan wajib pajak orang pribadi tahun pajak 2017 adalah sebanyak 47.466 sehingga perhitungan jumlah sampel untuk penelitian adalah sebagai berikut :

$$
\frac{47.466}{1+47.466(0,10)^{2}}=99,802(100)
$$

Jadi jumlah sampel dalam penelitian ini minimal adalah sebanyak 100 sampel

Teknik pengambilan sampel ini menggunakan Purposive sampling. Purposif sampling adalah salah satu teknik sampling non random sampling dimana peneliti menentukan pengambilan sampel dengan cara menetapkan ciri-ciri khusus yang sesuai dengan tujuan penelitian sehingga diharapkan dapat menjawab permasalahan penelitian. Kriteria yang ditetapkan untuk mengambil sampel dari populasi dalam penelitian ini adalah wajib pajak orang pribadi pengguna E-filling yang terdaftar di KPP Batam Selatan

\section{Teknik Pengumpulan Data}

Seperti dengan penelitian pada umumnya , maka data yang terkumpul dalam penelitian ini diperoleh dengan prosedur seperti berikut :

a. Kuesioner 
Kuesioner merupakan alat teknik pengumpulan data yang dilakukan dengan cara memberikan seperangkat pertanyaan atau pernyataan tertulis kepada responden untuk dijawabnya. Penelitian ini menggunakan kuesioner online yang disebarkan dengan membagikan link kuesioner kepada responden dan juga membagikan langsung kuesioner kepada responden.

b. Dokumen

Dokumen merupakan teknik pengumpulan data yang tidak ditujukan langsung kepada subjek penelitian, melainkan dengan meneliti dokumen-dokumen untuk bahan analisis misalnya biografi.

\section{Definisi Operasional Variabel}

a.Variabel Kepatuhan Wajib Pajak (Y)

Kepatuhan wajib pajak adalah rasa bersalah, rasa malu dan perilaku wajib pajak memenuhi segala kewajibannya.Indikator kepatuhan wajib pajak antara lain :

- Kepatuhan untuk mendaftarkan diri

- Kepatuhan dalam perhitungan dan pembayaran pajak terutang

- Kepatuhan dalam pembayaran tunggakan pajak

- Kepatuhan untuk menyetorkan kembali surat pemberitahuan

b. Variabel penerapan e-filling (X1) e-Filingadalah suatu cara penyampaian SPT Tahunan secara elektronik yang dilakukan secaraonline dan real time melalui internet pada website Direktorat Jenderal Pajak (www.pajak.go.id) atau Penyedia
Jasa Aplikasi atau Application Service Provider (ASP). Indikator variabel penerapan e-filling diantaranya adalah :

- Penyampaian SPT dapat dilakukan secara cepat, aman, kapan saja, dan dimana saja

- Murah, sehingga dapat menghemat biaya pada saat pelaporan SPT

- Mengurangi kesalahan dan keliruhan dalam menghitung karena telah menggunakan sistem computer

- Pengisian SPT lebih mudah karena berbentuk wizard

- Adanya validasi ketika pengisian SPT sehingga data

- Ramah lingkungan karena dapat mengurangi penggunaan kertas.

- Dokumen pelengkap tidak perlu dikirim lagi kepada fiskus kecuali diminta oleh KPP melalui account representative (AR).

c. Variabel Pemahaman Perpajakan (X2)

Pemahaman perpajakan adalah proses dimana wajib pajak mengetahui tentang perpajakan dan mengaplikasikan pengetahuan itu untuk membayar pajak. Indikatornya antara lain :

- Paham ketentuan umum dan tata cara perpajakan.

- Paham sistem perpajakan di Indonesia.

- Paham fungsi perpajakan.

- Paham apa saja sanksi perpajakan

\section{Pengujian Instrumen}

Data yang digunakan dalam uji coba instrumen diambil dari Wajib Pajak pengguna e-filing di KPP Batam Selatan. 
Pengambilan data menggunakan kuesioner dengan skala likert yang untuk mengukur Kepatuhan Wajib Pajak di KPP Batam selatan (Y), penerapan e-filing (X1), dan tingkat pemahaman perpajakan(X2). Uji coba instrumen dilakukan dengan menyebar 110 kuesioner dan yang kembali dan dapat diolah sebanyak 105 responden.

\section{a) Uji validitas}

Uji validitas adalah uji yang digunakan untuk menunjukkan sejauh mana alat ukur yang digunakan dalam suatu mengukur apa yang diukur. Ghozali (2009) menyatakan bahwa uji validitas digunakan untuk mengukur sah, atau valid tidaknya suatu kuesioner. Suatu kuesioner dikatakan valid jika pertanyaan pada kuesioner mampu untuk mengungkapkan sesuatu yang akan diukur oleh kuesioner tersebut.Pengujian validitas dilakukan menggunakan SPSS 17.0.Jika $r$ hitung $\geq \mathrm{r}$ tabel (uji 2 sisi dengan sig. 0,05) maka instrumen atau item-item pertanyaan berkorelasi signifikan terhadap skor total (dinyatakan valid).

\section{b) Uji reliabilitas}

MenurutGhozali (2009) menyatakan bahwa reliabilitas adalah alat untuk mengukur suatu kuesioner yang merupakan indikator dari peubah atau konstruk.Suatu kuesioner dikatakan reliabel atau handal jika jawaban seseorang terhadap pernyataan adalah konsisten atau stabil dari waktu ke waktu. Jika nilai alpha > 0.7 artinya reliabilitas mencukupi (sufficient reliability) sementara jika alpha $>0.80$ ini mensugestikan seluruh item reliabel dan seluruh tes secara konsisten memiliki reliabilitas yang kuat. Atau, ada pula yang memaknakannya sebagai berikut: Jika alpha > 0.90 maka reliabilitas sempurna. Jika alpha antara $0.70-0.90$ maka reliabilitas tinggi.Jika alpha $0.50-0.70$ maka reliabilitas moderat.Jika alpha $<0.50$ maka reliabilitas rendah.Jika alpha rendah, kemungkinan satu atau beberapa item tidak reliabel.

\section{Uji Asumsi Klasik}

Uji asumsi klasik merupakan pengujian yang dilakukan sebelum pengujian regresi .beberapa uji asumsi klasik yang harus dilakukan adalah Uji Normalitas, Uji Multikolinieritas, dan Uji Heteroskedastisitas.

\section{a) uji normalitas}

Uji normalitas adalah untuk melihat apakah nilai residual terdistribusi normal atau tidak. Model regresi yang baik adalah memiliki nilai residual yang terdistribusi normal

\section{b) uji multikolinearitas}

Uji multikolinieritas adalah untuk melihat ada atau tidaknya korelasi yang tinggi antara variabel-variabel bebas dalam suatu model regresi linear berganda.Jika ada korelasi yang tinggi di antara variabelvariabel bebasnya, maka hubungan antara variabel bebas terhadap variabel terikatnya menjadi terganggu.

\section{c) Uji heteroskedastisitas}

Uji heteroskedasitas adalah untuk melihat apakah terdapat ketidaksamaan varians dari residual satu ke pengamatan ke pengamatan yang lain. Model regresi yang memenuhi persyaratan adalah di mana terdapat kesamaan varians dari residual satu pengamatan ke pengamatan yang lain tetap atau disebut homoskedastisitas. Model regresi yang 


\section{- UNIVERSITAS RIAU KEPULAUAN BATAM}

baik seharusnya tidak terjadi heteroskedastisitas.

d) Uji autokorelasi

Uji autokorelasi adalah uji statistik yang digunakan untuk mengetahui ada atau tidaknya penyimpangan asumsi klasik autokorelasi yaitu korelasi yang terjadi antara residual pada suatu pengamatan dengan pengamatan lain pada model regresi.

\section{Pengujian Hipotesis}

\section{a. Uji Regresi Parsial (Uji t)}

Pengujian parsial (individual) diadakan dengan melakukan uji $t$ hitung dan membandingkan nilai sig dan nilai probabilitas, mencari besarnya $\mathrm{t}$ hitung yang akan dibandingkan dengan $\mathrm{t}$ tabel.

\begin{tabular}{|l|c|}
\hline \multicolumn{1}{|c|}{ Keterangan } & Jumlah \\
\hline Kuesioner yang disebarkan & 110 \\
\hline $\begin{array}{l}\text { Kusioner yang diisi dan } \\
\text { dapat diolah }\end{array}$ & 105 \\
\hline
\end{tabular}

Pengujian t hitung digunakan untuk

mengetahui kualitas keberartian regresi antara tiap-tiap variabel bebas $(\mathrm{X})$ terdapat pengaruh atau tidak terhadap variabel terikat (Y),Untuk menguji apakah hipotesis yang diajukan diterima atau ditolak digunakan statistik t (uji satu sisi).

\section{b. Uji regresi secara simultan (Uji F)}

Pengujian berganda (serempak) dengan melakukan uji $\mathrm{F}$ hitung, dengan mencari besarnya $\mathrm{F}$ hitung yang akan dibandingkan dengan $\mathrm{F}$ tabel. Pengujian $\mathrm{F}$ hitung digunakan untuk mengetahui kualitas keberartian regresi antara tiap-tiap variabel bebas (X) secara serempak/bersamaan terdapat pengaruh atau tidak terhadap variabel terikat (Y).

\section{Hasil penelitian dan pembahasan}

Karakteristik Responden yang digunakan pada penelitian ini diantaranya adalah :

- Jenis kelamin

- pendidikan terakhir

- jenis pekerjaan,

- pemahaman perpajakan,

- dan lama menggunakan e-fillling.

Berdasarkan data yang berhasil dikumpulkan dalam penelitian ini kuesioner online yang dibagikan sebanyak 20 responden dan kuesinoer yang disebar langsung kepada responden sebanyak 90 kuesioner, sehingga jumlah seluruh kuesioner yang tersebar adalah 110 kuesioner. Dari 110 kuesioner yang disebar yang kembali dan dapat diolah sebanyak 105 kuesioner.

Tabel 4.1

\section{Karakteristik Data}

Sumber data : data primer yang diolah

\section{Hasil Uji Validitas Setiap Variabel}

Hasil uji validitas yang dilakukan menunjukkan hasil yang valid karena setiap variabel memiliki nilai sig <0,05. Hasil setiap pengujian variabel dapat dilihat pada tabel berikut :

Tabel 4.2.

Hasil Uji Validitas Variabel Kepatuhan

(Y)

\begin{tabular}{|c|c|c|}
\hline Variabel & $\begin{array}{c}\text { Nilai } \\
\text { Sig }\end{array}$ & Keterangan \\
\hline KPT1 & 0,000 & Valid \\
\hline
\end{tabular}




\begin{tabular}{|l|l|l|}
\hline KPT2 & 0,000 & Valid \\
\hline KPT3 & 0,000 & Valid \\
\hline KPT4 & 0,000 & Valid \\
\hline
\end{tabular}

\begin{tabular}{|l|c|c|}
\hline \multicolumn{1}{|c|}{ Variabel } & $\begin{array}{c}\text { Cronch's } \\
\text { Alpha }\end{array}$ & Keterangan \\
\hline $\begin{array}{l}\text { Penerapan e- } \\
\text { filiing }\end{array}$ & 0,884 & Reliabel \\
\hline $\begin{array}{l}\text { Pemahaman } \\
\text { perpajakan }\end{array}$ & 0,808 & Reliabel \\
\hline Kepatuhan & 0,722 & Reliabel \\
\hline
\end{tabular}

Sumber data : data primer yang diolah

Tabel 4.3

\section{Hasil Uji Validitas Variabel Penerapan E-Filling (X1)}

Sumber data : data primer yang diolah

Tabel 4.4

Hasil Uji Validitas Variabel Pemahaman Perpajakan (X2)

\begin{tabular}{|c|c|c|}
\hline Variabel & Nilai sig & Keterangan \\
\hline PP1 & 0,000 & Valid \\
\hline PP2 & 0,000 & Valid \\
\hline PP3 & 0,000 & Valid \\
\hline PP4 & 0,000 & Valid \\
\hline PP5 & 0,000 & Valid \\
\hline
\end{tabular}

Sumber data : data primer yang diolah

\section{Hasil Uji Relibilitas}

Tabel 4.5

Hasil Uji Reliabilitas
Sumber data : data primer yang diolah

Berdasarkan tabel 4.5 dapat diketahui masing-masing variabel memiliki nilai Cronch's Alphalebih besar dari 0,7 yang menunjukkan bahwa masing- masing variabel dikatakan reliabel.

\begin{tabular}{|c|c|c|}
\hline Variabel & Nilai Sig & Keterangan \\
\hline PSE1 & 0,000 & Valid \\
\hline PSE2 & 0,000 & Valid \\
\hline PSE3 & 0,000 & Valid \\
\hline PSE4 & 0,000 & Valid \\
\hline PSE5 & 0,000 & Valid \\
\hline PSE6 & 0,000 & Valid \\
\hline PSE7 & 0,000 & Valid \\
\hline
\end{tabular}

\section{Hasil Uji Asumsi Klasik}

a) Uji Normalitas

Histogram

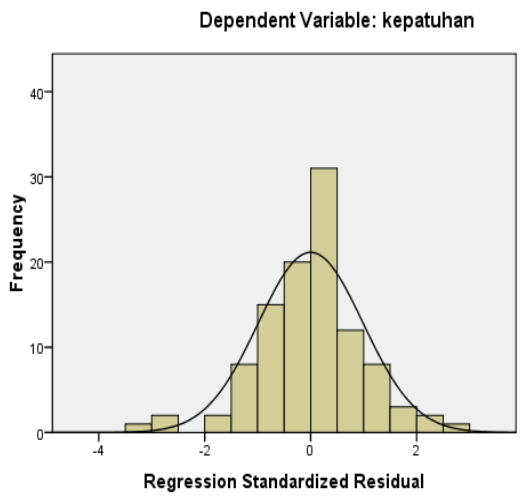

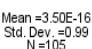

Gambar 1.

Hasil uji normalitas dengan SPSS 17.0 dapat dilihat data berdistribusi normal dengan melihat grafik histrogram adalah dengan melihat hasil grafik, apabila grafik tidak melenceng ke kiri atau ke kanan maka dapat dikatakan data berdistribusi normal. 
b) Uji multikoliniearitas

Tabel 4.6 Hasil Uji Multikolinearitas

Model Summary

\begin{tabular}{|c|c|c|c|c|c|}
\hline Mode & $\mathrm{R}$ & $\begin{array}{c}R \\
\text { Squar } \\
e\end{array}$ & $\begin{array}{l}\text { Adjusted } \\
R \text { Square }\end{array}$ & $\begin{array}{c}\text { Std. Error } \\
\text { of the } \\
\text { Estimate }\end{array}$ & $\begin{array}{l}\text { Durbin- } \\
\text { Watson }\end{array}$ \\
\hline 1 & $.478^{a}$ & .228 & .213 & 2.214 & 1.671 \\
\hline
\end{tabular}

a. Predictors: (Constant), pemahaman perpajakan, penerapan e-filling

b. Dependent Variable: kepatuhan

Berdasarkan hasil pengujian pada tabel 4.6 diatas karena VIF untuk semua variabel memiliki nilai VIF lebih kecil dari 10 dan nilai tolerance lebih besar dari 0,10 , maka dapat disimpulkan tidak terdapat multikolinearitas antar variabel independen.

\section{c) Uji Heteroskedastisitas}

Tabel 4.7

\section{Uji Heteroskedastisitas}

Berdasarkan tabel 4.7 diketahui nilai sig masing-masing variabel diatas 0,05 yang artinya tidak terjadi heteroskedastisitas.

\section{d) Uji autokorelasi}

Tabel 4.8

\section{Hasil Uji Autokorelasi}

Berdasarkan tabel 4.8 diatas dapat diketahui nilai DW 1,671 sedangkan dari tabel DW dengan signifikansi 0,05 dan jumlah data $(\mathrm{n})=105, \mathrm{k}=2$ diperoleh nilai dL sebesar 1,6433 dan dU sebesar 1,7209 dan dapat disimpulkan bahwa nilai DW $(1,387)$ berada pada daerah antara dL dan dU, maka tidak menghasilkan

\begin{tabular}{|c|r|r|}
\hline \multirow{2}{*}{ Model } & \multicolumn{2}{|c|}{ Collinearity Statistics } \\
\cline { 2 - 3 } & \multicolumn{1}{|c|}{ Tolerance } & \multicolumn{1}{c|}{ VIF } \\
\hline $1 \quad \begin{array}{l}\text { penerapan e- } \\
\text { filling } \\
\text { pemahaman } \\
\text { perpajakan }\end{array}$ & .722 & 1.385 \\
\hline
\end{tabular}

a. Dependent Variable: kepatuhan

kesimpulan yang pasti (berada di daerah keragu-raguan).

\section{Hasil Pengujian Hipotesis}

\section{a. Hasil Uji Parsial (Uji t)}

Berdasarkan hasil uji t pada tabel 4.9 diketahui nilai sig untuk variabel penerapan $e$-filling (X1) 0,038 $<0,05$ atau $\mathrm{t}$ hitung 2,100 > t tabel 1,983 yang artinya terdapat pengaruh signifikan antara variabel (penerapan $e$-filling) X1 terhadap kepatuhan wajib pajak orang pribadi (Y).

Coefficients $^{a}$

\begin{tabular}{|c|c|c|c|c|c|}
\hline \multirow[b]{2}{*}{ Model } & \multicolumn{2}{|c|}{$\begin{array}{c}\text { Unstandardized } \\
\text { Coefficients }\end{array}$} & \multirow{2}{*}{\begin{tabular}{|c|}
$\begin{array}{c}\text { Standar } \\
\text { dized } \\
\text { Coefficie } \\
\text { nts }\end{array}$ \\
Beta
\end{tabular}} & \multirow[b]{2}{*}{$t$} & \multirow[b]{2}{*}{ Sig. } \\
\hline & B & $\begin{array}{l}\text { Std. } \\
\text { Error }\end{array}$ & & & \\
\hline 1 (Constant) & 3.044 & 1.159 & & 2.627 & .010 \\
\hline $\begin{array}{l}\text { penerapan e- } \\
\text { filiing }\end{array}$ & -.068 & .042 & -.187 & -1.623 & .108 \\
\hline $\begin{array}{l}\text { pemahaman } \\
\text { perpajakan }\end{array}$ & .029 & .057 & .058 & .503 & .616 \\
\hline
\end{tabular}

a. Dependent Variable: RES2

Nilai sig untuk variabel pemahaman perpajakan (X2) 0,002<0,005 atau $\mathrm{t}$ hitung 3,206 > t tabel 1,983 yang artinya terdapat pengaruh signifikan antara 
variabel pemahaman perpajakan (X2) terhadap kepatuhan wajib pajak orang pribadi (Y).

Tabel 4.9

\section{Hasil Uji t}

\section{b. Hasil Uji Simultan (Uji F)}

Hasil uji $F$ pada tabel 4.10 dapat dilihat jika nilai sig sebesar $0,000<$ 0,005 dan nilai Fhitung 15,085 > Ftabel 3,08 sehingga dapat disimpulkan bahwa penerapan efilling dan pemahaman perpajakan berpengaruh signifikan terhadap kepatuhan wajib pajak orang pribadi

Tabel 4.10

Hasil uji F

\section{c. Koefisiensi Determinasi $\left(R^{2}\right)$}

Tabel 4.11

\section{Hasil Uji Koefisiensi Determinasi $\left(R^{2}\right)$}

Model Summary
\begin{tabular}{|l|c|r|r|r|}
\hline Mode & & $\begin{array}{c}\mathrm{R} \\
\mathrm{R}\end{array}$ & $\begin{array}{c}\text { Adjusted R } \\
\text { Square }\end{array}$ & $\begin{array}{c}\text { Std. Error of } \\
\text { the } \\
\text { Estimate }\end{array}$ \\
\hline 1 & $.478^{\mathrm{a}}$ & .228 & .213 & 2.214 \\
\hline
\end{tabular}

a. Predictors: (Constant), pemahaman perpajakan, penerapan e-filling

Hasil Koefisiensi determinasi $\left(R^{2}\right)$ pada tabel 4.11 menunjukkan nilai $\mathrm{R}$ Square sebesar 0,228. Hal ini berarti 22,8\% variabel kepatuhan wajib pajak orang pribadi dapat dijelaskan oleh variabel independen yaitu penerapan e-filiing dan pemahaman perpajakan, sisanya

Coefficients $^{a}$

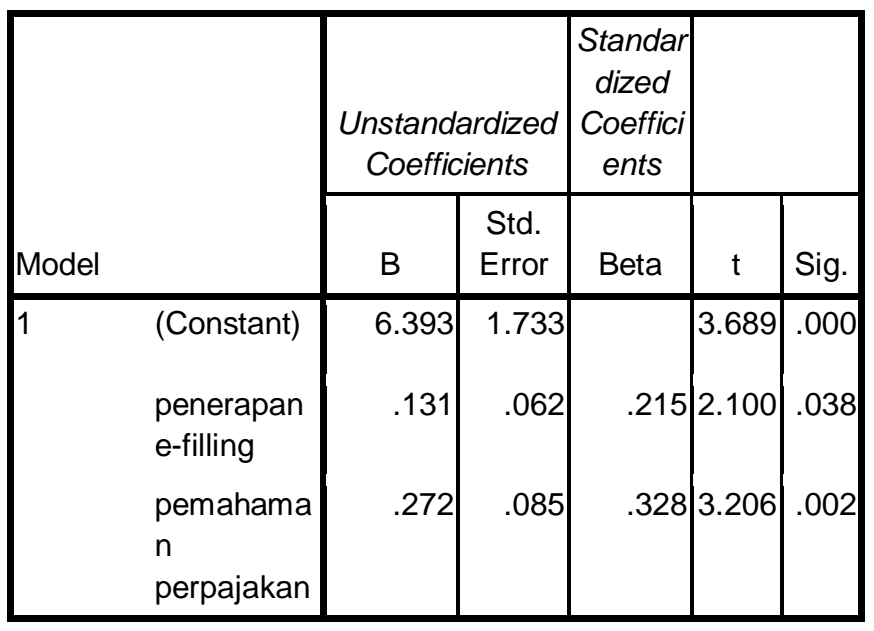

dijelasakan oleh variabel lain di luar model.

\section{PEMBAHASAN}

a. Pengaruh Penerapan E-Filling

Terhadap Kepatuhan Wajib Pajak Orang Pribadi

ANOVA $^{b}$

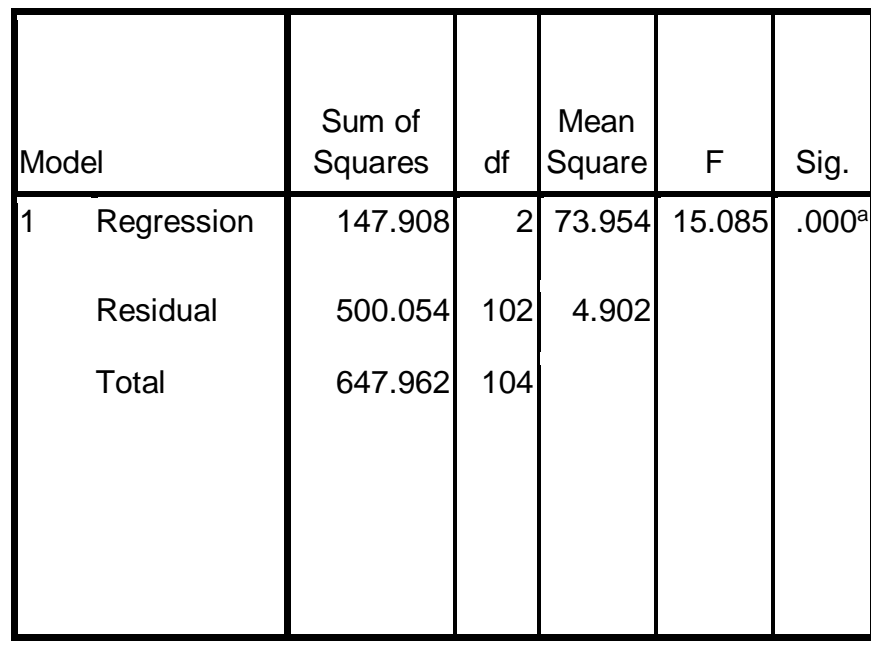

Hasil uji hipotesis menunjukkan bahwa penerapan e-filling berpengaruh signifikan terhadap kepatuhan wajib pajak orang pribadi di KPP Pratama Batam Selatan.Berdasarkan tabel 4.9 
dapat dilihat bahwa variabel penerapan $e$-filling memiliki nilai t hitung 2,100 sedangkan $\mathrm{t}$ tabel 1,983 yang artinya $\mathrm{t}$ hitung > t tabel dan nilai sig 0,038 < 0,005 maka Ho di tolak dan $\mathrm{Ha}$ diterima.Hal ini menunjukkan bahwa penerapa e-filiing berpengaruh positif dan signifikan terhadap kepatuhan wajib pajak orang pribadi.Hasil ini konsisten dengan hasil penelitian yang dilakukan oleh Agustiningsih (2016) yang menunjukkan penerapan $e$ fillingberpengaruh positif dan signifikan terhadap kepatuhan wajib pajak.

\section{b. Pengaruh Pemahaman Perpajakan TerhadapKepatuhan Wajib Pajak Orang Pribadi}

Hasil uji hipotesis yang telah dilakukan menunjukkan bahwa pemahaman perpajakan berpengaruh signifikan terhadap kepatuhan wajib pajak orang pribadi di KPP Pratama Batam Selatan. Berdasarkan tabel 4.9 dapat dilihat nilai sig yang diperoleh adalah sebesar 0,002 yang artinya lebih kecil dari 0,05dan juga dapat dilihat bahwa variabel pemahaman perpajakan memiliki nilai t hitung 3,206 > t tabel 1,983. Hal ini dapat disimpulkan bahwa pemahaman perpajakan berpengruh positif dan signifikan terhadap terhadap kepatuhan wajib pajak.Hasil penelitian ini konsisten dengan hasil penelitian Agustiningsih (2016) yang menunjukkan bahwa pemahaman perpajakan berpengaruh positif dan signifikan terhadap kepatuhan wajib pajak.Hasil ini juga konsisten dengan penelitian Arifin
(2014) yang menjelaskan pengetahuan dan pemahaman perpajakan berpengaruh terhadap kemauan membayar pajak.Namun pada penelitian Jayanti (2017) menjelaskan hasil yang berbeda yaitu pemahaman tidak berpengaruh signifikan terhadap kepatuhan wajib pajak.

\section{c. Pengaruh Penerapan E-Filling Dan Pemahaman Perpajakan Terhadap Kepatuhan Wajib Pajak Orang Pribadi}

Hasil uji hipotesis menunjukkan bahwa penerapan e-filling dan pemahaman perpajakan berpengaruh signifikan terhadap kepatuhan wajib pajak orang pribadi. Pada tabel 4.10dapat dilihat bahwa variabel independen memiliki nilai $\mathrm{F}$ hitung sebesar 15,085 > F tabel sebesar 3,08 dan nilai sig sebesar $0,000<0,05$ yang artinya variabel indenpenden berpengaruh signifikan terhadap variabel dependen. Hal ini konsisten dengan penelitian sebelumnya yaitu pada penelitian Agustiningsih (2016) yang menyatakan bahwa penerapan efilling dan pemahaman perpajakan berpengaruh signifikan terhadap kepatuhan wajib pajak.

\section{KESIMPULAN DAN SARAN}

\section{Kesimpulan}

Penelitian ini bertujuan untuk mengetahui pengaruh penerapan $e$ filling dan pemahaman perpajakan terhadap kepatuhan wajib pajak orang pribadi pada KPP Batam Selatan.Responden penelitian ini 
berjumlah 105 orang. Berdsarkan data yang sudah dikumpulkan dan pengujian yang telah dilakukan, maka dapat ditarik kesimpulan sebagai berikut :

1. Pengaruh penerapan e-filling berpengaruh signifikan terhadap kepatuhan wajib pajak orang pribadi dengan nilai sig sebesar (0,038).

2. Pengaruh pemahaman perpajakan berpengaruh signifikan terhadap kepatuhan wajib pajak orang pribadi dengan nilai sig sebesar $(0,002)$

3. Pengaruh penerapan e-filling dan pemahaman perpajakan secara simultan berpengaruh signifikan terhadap kepatuhan wajib pajak orang pribadi dengan nilai sig sebesar $(0,000)$ dan $F$ hitung sebesar 15,085 > F tabel sebesar 3,08 .

\section{Saran}

Berdasarkan hasil penelitian dan kesimpulan maka saran-saran yang dapat diberikan dengan judul adalah sebagai berikut :

1. Dilihat dari hasil penelitian yang menunjukkan bahwa penerapan $e$ filling dan pemahaman perpajakan berpengaruh signifikan terhadap kepatuhan wajib pajak orang pribadi, maka hasil ini penelitian dapat dijadikan bahan pertimbangan untuk lebih mensosialisaikan tentang manfaat pajak dan penggunaan e-filling sehingga diharapkan dapat meningkatkan kepatuhan wajib pajak orang pribadi,

2. Penyuluhan pajak perlu ditingkatkan dan difokuskan pada materi tentang sistem perpajakan, hak dan kewajiban wajib pajak sehingga pemahaman wajib pajak tentang perpajakan bertambah luas dan dapat memacu diri wajib pajak membayar pajak.

3. Bagi peneliti selanjutnya yang ingin menggunakan variabel $e$ filling diharapkan dapat memperluas lokasi penelitian. Hal ini diharapkan agar dapat membandingkan hasil penerapan $e$ filling dan peneliti selanjutnya juga dapat menambahkan variabel lainnya untuk mendapatkan hasil yang lebih baik.

\section{DAFTAR PUSTAKA}

Agustiningsih, Wulandari. 2016.

Pengaruh Penerapan E-Filling, Tingkat Pemahaman Perpajakan Dan Kesadaran Wajib Pajak Terhadap Kepatuhan Wajib Pajak Di KPP Pratama Yogyakarta”. Jurnal Nominal, Vol. 5,No.2.

Arifin, Z. N. 2014. "Analisis faktorfaktor yang mempengaruhi kemauan wajib pajak untuk membayar pajak penghasilan: studi kasus wajib pajak orang pribadi yang terdaftar di KPP Pratama 
Bekasi Utara". Skiripsi feb. Universitas Muhammadiyah

Surakarta.

Arikunto, S. (2010).Prosedur penelitian suatu pendekatan praktik.Rineka cipta.

Chaizi Nasucha, 2004, Reformasi Administrasi Publik. Jakarta: PT. Grasindo

Erard, B dan Jonathan Feinstein. 1998. Tax Compliance. Journal of Economic Literature. Vol, XXXVI, pp. 818-860.

Fajri, E. Z dan Ratu Aprlia Senja.(2008). Kamus lengkap bahasa Indonesia, Semarang: Difa Publisher.

Ghozali, I. (2016). Aplikasi analisis multivariate dengan program IBM SPSS 23. Semarang. BPFE Universitas Diponegoro.

Hardiningsih, P. 2011. Faktor-faktor yang mempengaruhi kemauan membayar pajak. Dinamika keuangan dan pebankan, Vol.3, No. 1, Hal: 126-142.

Hasan, A. (2013). Marketing dan kasus-kasus pilihan.Yogyakarta . CAPS

Havid, M. 2017. Pengaruh penerapan e-filling terhadap tingkat kepatuhan wajib pajak (studi survey pada kantor pelayanan pajak pratama bandung cibeunying). Skripsi.Bandung : Universitas Widyatama.

Jatmiko, A. N. 2006. "Pengaruh sikap wajib pajak pada pelaksanaan sanksi denda, pelayanan fiskus dan kesadaran perpajakan terhadap kepatuhan wajib pajak (studi empiris terhadap wajib pajak orang pribadi di kota Semarang)'.Tesis.Semarang : Universitas Diponegoro.

Jayanti, E. D. 2017. "pengaruh penerapan sistem e-filling, pemahaman dan kesadaran wajib pajak terhadap kepatuhan wajib pajak". Artikel ilmiah.Surabaya : Sekolah Tinggi Ilmu Ekonomi Perbanas.

Kelebihan e-spt. Dalam https://www.kemenkeu.go.id/p age/aplikasi-elektronik-e-sptorang-pribadi/

Lelena, Y. A. 2015. KPP: Kepatuhan Wajib Pajak Dibatam Rendah. Dalam https://www.wartaekonomi.co.id/r ead51067/kpp-kepatuhan-wajib- 
pajak-di-batam-rendah.html, 12

September 2018.

Nursalim, L. A. 2017. "Pengaruh Penerapan Sistem E-Filling Terhadap Kepatuhan Wajib Pajakdengan Pemahaman Internet Sebagai Variabel Pemoderasi Pada Kantor Pelayanan Pajak Pratam Makassar

Selatan”.Skripsi.Makassar

Universitas Muslim Indonesia.

Peraturan Dirjen Pajak nomor 39/PJ/2011 tentang "Tata Cara Penyampaian Surat Pemberitahuan Tahunan Wajib Pajak Orang Pribadi Yang Menggunakan Formulir 1770S Atau 1770SS Secara E-Flling Melalui Website Direktorat Jendral Pajak (www.pajak.go.id)"

Pranoto.(2007). Kamus besar bahasa Indonesia. Jakarta: Gramedia.

Qomaria, Siti. 2008. Analisis Pengaruh Pengetahuan Tentang Pajak Dan Tingkat Pada KPP Pratama Kebayoran Baru Tiga.Skripsi.Fakultas Ekonomi Dan Ilmu Sosial. Jakarta. Universitas Islam Negeri Syarif Hidayatullah.
Sabar, R. (2007). Pengantar metodologi penelitian. Fkip: Universitas Muria Kudus

Sugiyono. (2016). Metode Penelitian Kuantitatif, Kualitatif dan R\&D. Bandung: PT Alfabet.

Soemitro, R. dan Dewi, K. S. (2010).Asas dan Dasar Perpajakan (1), Bandung: Refika Aditama.

Tjahono, M. B .2018.Sudah cukupkah kepatuhan pajak kita.Dalam http://pajak.go.id/article/sudahcukupkah-kepatuhan-pajak-kita， 20 September 2018.

Umar, H. (2011). Metode penelitian untuk skripsi dan tesis bisnis. Rajawali pers 